УДК 373.3.014.3

DOI:

Алла Харківська, доктор педагогічних наук, професор, проректор з науково-педагогічної роботи Комунального закладу “Харківська гуманітарно-педагогічна академія” Харківської обласної ради

\title{
ОСНОВНІ ШЛЯХИ ПЕДАГОГІЧНОЇ ВЗАЕМОДІЇ ШКОЛИ ТА СІМ’ї У ВИХОВАННІ МОЛОДШИХ ШКОЛЯРІВ
}

У статті проаналізовані дефініції “педагогічна взаємодія” $і$ “взаємодія школи та сім '̈”. Виявлено, щзо ключову роль у сучасній реформі відведено педагогам як агентам змін, які використовуючи закорінені в начіональній педагогічній традиції позитивні здобутки, побудують нові взаємовідносини між учасниками освітнього процесу на засадах взаєморозуміння, спільності інтересів у прагненні до якісної освіти. Обтрунтовано, що педагогічна взаємодія - це взаємний вплив педагогів та батьків один на одного, в результаті чого відбувається виховання молодщих школярів. Це завдання реалізовується у спільній діяльності учителя з батьками, а також передбачає їх взаєморозуміння, спільність інтересів та прагнень.

Ключові слова: педагогічна взаємодія; взаємодія школи та сім'ї; напрями роботи з батьками; фактори взасмодії сім'ї та школи; форми роботи школи з батьками.

Jim. 9.

Alla Kharkivska, Doctor of Sciences (Pedagogy), Professor, Vice Rector of Scientifically Pedagogical Works Municipal Establishment “Kharkiv Humanitarian-Pedagogical Academy”of the Kharkiv Regional Council

\section{MAIN WAYS OF PEDAGOGICAL INTERACTION BETWEEN SCHOOLAND FAMILY IN THE EDUCATION OF YOUNG SCHOOLCHILDREN}

The article analyzes and identifies the main ways of pedagogical interaction between school and family in the education of primary school children. The author grounded the definition of "educational cooperation" and "interaction between schools and families". It was found that the key role in modern reform is given to teachers as agents of change, who using the positive achievements rooted in the national pedagogical tradition, build new relationships between participants in the educational process on the basis of mutual understanding, common interests in the pursuit of quality education. It was found that effective pedagogical interaction of teachers with families of primary school students requires new mechanisms of continuous education of primary school teachers and finding the main ways of pedagogical interaction of school and family in the education of primary school children. It is determined that pedagogical interaction is a mutual influence of teachers and parents on each other, as a result of which the education of junior schoolchildren takes place. This task is implemented in the joint activities of the teacher with parents, and also involves their mutual understanding, common interests and aspirations. The structure of pedagogical interaction is formed by interdependencies: educational, pedagogical, sociopsychological, interpersonal systems; regulatory and executive elements of interaction. The factors that help the school to involve parents are proposed and characterized, namely: the use of family-oriented pedagogical practices; methodical recommendations for successful interaction of teachers with families of students, etc. The most common forms of school work with parents, which are relevant for our study: individual forms (visiting parents of students; inviting parents to school; correspondence with parents); group (evenings of questions and answers; conversations and lectures for parents; work with parents' assets); collective (class parent meetings; thematic meetings of parents; conferences on exchange of experience of education of children). We believe that using our proposed ways of interaction and involving parents in the educational process, teachers will be able to obtain additional information from parents about children and help them in the education of primary school children, together with parents to build an educational trajectory of child development.

Keywords: pedagogical interaction; school-family interaction; areas of work with parents; family-school interaction factors; forms of school work with parents.

Постановка проблеми у загальному вигляді та її зв'язок із важливими науковими чи практичними завданнями. Освітні реформи в Україні акцентують увагу на проблемі побудови якісно нових взаємовідносин між учасниками освітнього процесу. Ключову роль у сучасній реформі відведено педагогам як

агентам змін, які, використовуючи закорінені в національній педагогічній традиції позитивні здобутки, побудують нові взаємовідносини між учасниками освітнього процесу на засадах взаєморозуміння, спільності інтересів у прагненні до якісної освіти.

Ефективна педагогічна взаємодія учителів із 
сім'ями молодших школярів вимагає нових механізмів безперервної освіти вчителів початкової школи і пошуку основних шляхів педагогічної взаємодії школи та сім’ї у вихованні молодших школярів.

Аналіз основних досліджень і публікацій. Педагогічну взаємодію як наукову категорію досліджували І. Бех, О. Буздуган, Г. Ващенко, Б. Гершунський, О. Гребенюк, М. Свтух, Г. Ковальов, А. Лякішева, О. Матвієнко, О. Микитюк, Н. Побірченко, Н. Пузиркова, О. Рацул, О. Рудницька, Т. Цуркан, О. Яструб та ін. Особливості педагогічної взаємодії школи та сім'ї у вихованні молодших школярів висвітлили у свої працях Т. Алексєєнко, О. Алєко, Н. Андрущенко, О. Антипова, Т. Виноградова, Ю. Грицкова, Н. Дудник, Л. Зінченко, А. Колишкіна, А. Марушкевич, О. Савченко, В. Тименко та ін. Теоретикометодологічним засадам формування культури родинних взаємин у сучасних сім'ях присвятили свої наукові дослідження Л. Буніна, О. Докукіна, Б. Ковбас, В. Костів, Л. Островська, Т. Шанскова та ін.

Роль взаємодії школи та сім'ї підкреслено у законодавчій базі: Законі України "Про освіту”, Національній доктрині розвитку освіти України у XXI ст., постанові Президї АПН України "Про Національну програму виховання дітей та учнівської молоді в Україні”, Указі президента "Про національну стратегію розвитку освіти в Україні на період до 2021 року”, Концепції “Нова українська школа" та ін.

Мета статті. Проаналізувати і виокремити основні шляхи педагогічної взаємодії школи та сім'ї у вихованні молодших школярів.

Виклад основного матеріалу дослідження. Окреслена нами проблема дослідження безпосередньо пов'язана 3 пошуком i виокремленням основних шляхів педагогічної взаємодії школи та сім’ї у вихованні молодших школярів. Однак спершу, доцільно визначитися зі змістом понять “педагогічна взаємодія” й “взаємодія школи та сім'э”.

У монографії Л. Велитченка "Педагогічна взаємодія: теоретичні основи психологічного аналізу” педагогічна взаємодія проаналізована як “системне явище в педагогічному процесі, що зазнає впливу з боку соціальної системи у плані статусно-рольових відносин у суспільстві, регламентується нормативними документами в системі освіти, визначається практикою освітнього закладу, реалізується вчителем, діяльність якого є основою для розвитку діяльності учня”. Структуру педагогічної взаємодії утворюють взаємозалежності: освітньої, педагогічної, соціально-психологічної, міжособистісної систем; регулятивних і виконавчих елементів взаємодії [2].

Уважаємо, що найгрунтовніше характеристику поняття “педагогічна взаємодія" здійснила у дисертаційній роботі С. Мартиненко, яка визначає його “як детерміновану освітню ситуацію, опосередковану соціально-психологічними процесами і зв'язок суб'єктів (і об'єктів) освіти, що веде до кількісних і / або якісних змін якостей і станів цих суб'єктів і об'єктів” $[5,13]$. Аналіз іiі роботи дав нам змогу узагальнити такі характеристики педагогічної взаємодії: спільна діяльність суб'єктів освітнього процесу; основні параметри: взаємини, взаємоприйняття, підтримка та довіра; передбачає актуалізацію суб'єкт-суб'єктних стосунків; має чітку структуру, представлену сферами: спілкувальною, діяльнісною, відносин, когнітивно-ціннісною; провідна роль належить соціальним установкам.

У контексті нашого дослідження педагогічна взаємодія, може розглядатись як взаємний вплив педагогів та батьків один на одного, в результаті чого відбувається виховання молодших школярів. Це завдання реалізовується у спільній діяльності учителя $з$ батьками, а також передбачає їх взаєморозуміння, спільність інтересів та прагнень.

Характеризуючи поняття “педагогічна взаємодія школи та сім'і”, Т. Цуркан визначає такі особливості цього процесу: оптимальна умова створення цілісного освітнього простору сім'ї та школи - побудова соціального партнерства педагогів та батьків учнів; педагогічна просвіта батьків учнів - провідна функція педагогічного колективу; спільна діяльність базується на життєвому досвіді батьків, спрямованому педагогами на отримання нових знань; будь-який процес має бути системним та безперервним $[9,7]$.

М. Бевзюк виокремила такі напрями взаємодії вчителів початкової школи із батьками їхніх учнів: середовищний: створення оптимального для молодших школярів освітнього середовища класного навчання за різними сферами: психологічною (батьківське та вчительське консультування індивідуальне і групове); матеріально-технічною (оснащення й обладнання класної кімнати та школи); методичною (батьківські та вчительські консультації навчального характеру); виховною (батьківські та вчительські консультації виховного характеру); медичною (медичні консультації); творчою (батьківські та вчительські консультації щодо розвитку творчих задатків молодших школярів); пізнавально-дозвіллєвий шкільного рівня: організація пізнавальної та дозвіллєвої діяльності 


\section{ОСНОВНІ ШЛЯХИ ПЕДАГОГІЧНОЇ ВЗАЕМОДЇ ШКОЛИ ТА СІМ’̈̈ У ВИХОВАННІ МОЛОДШИХ ШКОЛЯРІВ}

молодших школярів у закладі освіти (зокрема, формування традицій класу: спеціальне святкування іменин, різних свят тощо); пізнавально-дозвіллевий сімейного рівня: організація пізнавальної та дозвіллєвої діяльності молодших школярів удома; просвітній: педагогічна просвіта батьків учнів з організацією способів обміну досвідом батьків у освіті та дозвіллі дітей; проєктний: розробка та виконання освітніх та дозвіллєвих творчих проєктів; організаційний: участь у класних, загальношкільних та позашкільних структурах і громадських організаціях: батьківські комітети та інші структури/ організації, волонтерство тощо [1].

C. Єфімовою було запропоновано та схарактеризовано фактори, що допомагають школі залучати батьків, а саме: використання педагогічних практик, орієнтованих на сім'ю; методичні рекомендації для успішної взаємодії педагогів з сім'ями учнів. Дослідниця зазначає, що “одним 3 найважливіших завдань адміністрації та педагогів, i, водночас, першим кроком на шляху налагодження довірливих, партнерських стосунків з родинами є створення такого середовища, де б дитина почувалася комфортно і впевнено" [3].

На усвідомленні необхідності педагогічної взаємодії школи та сім'ї у вихованні молодших школярів наголошують автори "Родинної педагогіки” Б. Ковбас та В. Костів. Розв’язання цієї проблеми у сімейно-шкільній взаємодії зумовлює розробку та реалізацію системи відповідних заходів у загальношкільному й класному планах виховної роботи. В цьому аспекті використовуються найменші можливості навчальних предметів і специфічних видів позакласної і позашкільної виховної взаємодії учителів та батьків.

Б. Ковбас та В. Костів пропонують таку тематику диференційованих групових занять та індивідуальної просвітницької діяльності для батьків молодших школярів [4, 241-243]:

1.Анатомо-фізіологічнітаіндивідуально-психологічні особливості розвитку молодших школярів.

2. Рухливі ігри та фізичний розвиток молодших школярів.

3. Роль книги у розвитку дитини. Батьки й техніка дитячого читання.

4. Формування інтелектуальної культури. Розвиток ранньої обдарованості дитини. Комп’ютерні ігри.

5. Особливості комунікативного розвитку молодших школярів. Діти і спілкування, формування колективістських умінь і навичок, індивідуалізація дитини.
6. Формування елементів духовної культури дитини. Діти і Бог, діти і релігія.

7. Особливості морального розвитку молодших школярів. Формування елементів культури поведінки.

8. Формування трудових умінь і навичок.

9. Естетичний розвиток дитини. Включення молодших школярів до різних видів дитячої творчості.

10. Прищеплення у молодших школярів любові до природи (флори і фауни).

11. Організація і проведення сімейного дозвілля. Діти і телебачення.

12. Формування умінь і навичок культури сім'янина.

У підручнику М. Фіцули “Педагогіка" [8, 402] зазначено, що: "Успішна виховна робота з дітьми не можлива без постійного співробітництва школи і сім’і, метою якого є узгодження, координування виховних впливів. 3 цією метою педагоги використовують такі форми і методи роботи 3 батьками учнів, як відвідування їх удома, запрошення їх до школи, дні відкритих дверей у школі, класні батьківські збори та ін.”.

Найбільш поширені форми роботи школи з батьками, які є актуальними для нашого дослідження виокремив С. Мельничук [6]. Педагог поділив їх на три групи: індивідуальні, групові та колективні. Розглянемо їх детальніше.

1. Індивідуальні форми:

- відвідування батьків школярів (вчитель заздалегідь планує цей вид роботи: графік відвідування, дні консультацій; учитель має змогу ознайомитися з соціально-економічними умовами виховання дитини в сім'ї; зрозуміти психологопедагогічний клімат у сімейному колективі; дати поради батькам щодо забезпечення сприятливих умов для навчальної діяльності учня; інформувати батьків про успішність і поведінку вихованця у школі та ін.);

- запрошення батьків до школи (вчителі не завжди мають можливість відвідати батьків учнів, тому батьки нерідко запрошуються до школи для бесіди щодо виховання і навчання учнів; такі зустрічі допомагають спільно подолати ці проблеми; мета таких зустрічей може бути різною (з'ясування умов життя та кола обов'язків дітей у сім’і; обговорення конкретних випадків поведінки учнів; накреслення спільних шляхів усунення недоліків у навчальній діяльності, праці і повсякденному житті; поради про раціональні способи виконання домашніх завдань; поради щодо організації позакласного читання; поради щодо залучення дітей до побутової праці; інформація батькам про успіхи в навчанні і 


\section{ОСНОВНІ ШЛЯХИ ПЕДАГОГІЧНОӤ ВЗАЄМОДІЇ ШКОЛИ ТА СІМ'Ї У ВИХОВАННІ МОЛОДШИХ ШКОЛЯРІВ}

поведінці; поради щодо створення умов для розвитку творчих задатків дітей у будь-якій галузі; поради щодо необхідності режиму дня дітей тощо); запрошуючи батьків, слід пам'ятати, що вони потребують кваліфікованої поради, товариської допомоги та взаєморозуміння) [6];

- листування з батьками (ця форма зв'язку позитивно впливає на налагодження добрих взаємин учителя 3 батьками, піднесення авторитету як батьків, так і вчителів; сприяє створенню взаємин довіри та поваги між учителем і сім'ями вихованців; у сучасних умовах листування відбувається за допомогою месенджерів Viber, WhatsApp, Telegram тощо; головні переваги такого спілкування: цей спосіб надає максимальну оперативність обміну інформацією; за допомогою таких програм можна організувати як колективну, так і індивідуальну розсилку повідомлень; висока мобільність використовуючи фотокамеру телефона, можна робити фото або відео та відразу ж викладати його в групі [7).

2. Групові:

- вечори запитань і відповідей (проводяться 3 метою підвищення педагогічної культури батьків; питання подаються у письмовій формі заздалегідь, але додаткові можуть додаватися і усно; для надання відповідей на запитання батьків залучаються не лише вчителі, а й психологи, медики, юристи, працівники міліції та ін.);

- бесіди та лекції для батьків (проводяться 3 метою пропаганди педагогічних знань для батьків певного класу; дають можливість висвітлити питання виховання з урахуванням вікових особливостей учнів; бесіди і лекції досягають своєї мети, якщо вони проводяться систематично та регулярно; тематика лекцій і бесід складається на основі запитів та інтересів батьків);

- робота з активом батьків (розв'язання різних організаційних питань, наприклад екскурсій, прогулянок тощо) [6].

3. Колективні:

- класні батьківські збори (найбільш поширена форма роботи вчителя з батьками учнів; збори батьків проводяться на початку навчального року і в кінці семестру, а також перед початком осінніх, зимових і весняних канікул з метою ознайомлення батьків із завданнями і станом навчальної та виховної роботи в класі; у разі потреби збори можуть бути проведені у будь-який зручний для батьків час; на них розглядаються найважливіші питання навчання і виховання дітей у школі та вдома; батьківські збори мають відповідати таким педагогічним вимогам: сприяти формуванню згуртованого батьківського колективу, виховувати соціально-правову відповідальність батьків за виховання дітей; проводитися систематично, забезпечувати наступність у розв'язанні виховних завдань; забезпечувати оптимальні умови для оволодіння батьками психолого-педагогічними знаннями в галузі сімейного виховання; сприяти забезпеченню єдності виховних впливів школи та сім'ї на вихованців; забезпечувати формування узгодженої колективної думки, яка позитивно впливала б на процес виховання; сприяти підвищенню авторитету вчителів-вихователів школи та батьків; показувати батькам успіхи їх дітей у навчанні та вихованні як результат діяльності учителів-вихователів тощо;

- тематичні збори батьків (мета зборів озброїти батьків конкретними педагогічними знаннями, ознайомити 3 кращим досвідом виховання дітей; тематика таких зборів може бути запропонована вчителем, або ж за проханням батьків);

- конференції щодо обміну досвідом виховання дітей (на них батьки діляться власним досвідом подолання різних проблем; на конференції бажано більш уваги приділити розкриттю важких питань виховання дітей у сім'ї, порадити шляхи їх розв'язання) [6].

Уважаємо, що при виборі форм педагогічної взаємодії школи та сім’ї слід враховувати корелятивність форми роботи з батьками (батьки пасивні слухачі / або активі учасники виховного процесу дитини), які в процесі спілкування (обговорення, дискусії) конструюють нову модель взаємодій та взаємостосунків.

Висновки 3 даного дослідження i перспективи подальших розвідок у даному напрямку. Нові реалії життя потребують пошуку нових шляхів педагогічної взаємодії школи та сім'ї. Під активізацією педагогічної взаємодії школи та сім'ї ми розуміємо процес, що сприяє: виробленню педагогічної позиції педагогів і батьків для розв'язання спільних питань і завдань виховання на основі інтеграції навчальної і виховної діяльності; творчому втіленню теоретичних знань і практичних умінь у практику виховання, виробленню мотиваційної потреби до продукування принципово нових форм, методів і засобів взаємодії школи та сім'ї; розвитку здатності учителів і батьків до свідомого й узгодженого регулювання процесу виховання школярів, внесення своєчасної корекції у виховний процес на основі педагогічної рефлексії. Використовуючи запропоновані нами шляхи взаємодії та залучаючи батьків до виховного процесу, вчителі зможуть отримати від них 
додаткову інформацію про дітей та надати їм допомогу у вихованні молодших школярів, спільно вибудовувати освітню траєкторію розвитку дитини.

\section{ЛІТЕРАТУРА}

1. Бевзюк М. С. Підготовка майбутніх учителів початкової школи до взаємодії з батьками в умовах інклюзивного навчання : дис. ... канд. пед. наук : 13.00.04. Умань, 2019. 267 с.

2. Велитченко Л. К. Педагогічна взаємодія: теоретичні основи психологічного аналізу : монографія. Одеса, 2005. 355 с.

3. Єфімова С. М. Налагодження партнерських стосунків з родинами. Інклюзивна школа: особливості організаиії та управління : навч.метод. посіб. Київ, 2007. С. 37-42.

4. Ковбас Б., Костів В. Родинна педагогіка : навчально-методичний посібник. Т. 2. ІваноФранківськ, 2006. 288 с.

5. Мартиненко С. М. Діагностування особистіснопрофесійної готовності вчителя початкової школи до педагогічної діяльності. Рідна мова : освітній квартальник Украӥнського вчительського товариства у Польщі. 2012. № 17. С. 34-43.

6. Мельничук С. Г. Педагогіка (Теорія виховання) : навчальний посібник. Київ, 2012.288 с.

7. Ткачук I.B. 11 Сучасних способів зв'язку 3 батьками учнів. URL : http://klasnaocinka.com.ua/ ru/article/11-suchasnikh-sposobiv-zvyazku-zbatkami-uchniv.html.

8. Фіцула М. М. Педагогіка : навчальний посібник. Київ, 2007. 506 с.

9. Цуркан Т. Г. Формування педагогічної культури батьків молодших школярів у взаємодії сім’ї і школи : дис. ... канд. пед. наук : 13.00.07. Чернівці, 2018.340 с.

\section{REFERENCES}

1. Bevziuk, M. S. (2019). Pidhotovka maibutnikh uchyteliv pochatkovoi shkoly do vzaiemodii z batkamy $\mathrm{v}$ umovakh inkliuzyvnoho navchannia [Preparation of future primary school teachers for interaction with parents in the conditions of inclusive education]. Candidate's thesis. 267 p. [in Ukrainian].

2. Velytchenko, L. K. (2005). Pedahohichna vzaiemodiia: teoretychni osnovy psykholohichnoho analizu [Pedagogical interaction: theoretical bases of psychological analysis]. Odesa, 355 p. [in Ukrainian].

3. Yefimova, S. M. (2007). Nalahodzhennia partnerskykh stosunkiv $\mathrm{z}$ rodynamy [Establishing partnerships with families]. Inclusive school: the features of organization and management: a training manual. Kyiv. pp. 37-42. [in Ukrainian].

4. Kovbas, B. \& Kostiv, V. (2006). Rodynna pedahohika [Family pedagogy]. Training manual. Vol. 2. Ivano-Frankivsk, 288 p. [in Ukrainian].

5. Martynenko, S. M. (2012). Diahnostuvannia osobystisno-profesiinoi hotovnosti vchytelia pochatkovoi shkoly do pedahohichnoi diialnosti [Diagnosing the personal and professional readiness of primary school teachers for teaching]. Native language: educational quarterly of the Ukrainian Teachers' Association in Poland. No. 17. pp. 34 43. [in Ukrainian].

6. Melnychuk, S. H. (2012). Pedahohika (Teoriia vykhovannia) [Pedagogy (Theory of education)]. Training manual. Kyiv, 288 p. [in Ukrainian].

7. Tkachuk, I. V. 11 Suchasnykh sposobiv zviazku z batkamy uchniv [Modern ways to communicate with students' parents]. Available at: http:// klasnaocinka.com.ua/ru/article/11-suchasnikhsposobiv-zvyazku-z-batkami-uchniv.html. [in Ukrainian].

8. Fitsula, M. M. (2007). Pedahohika [Pedagogy]. Training manual. Kyiv, 506 p. [in Ukrainian].

9. Tsurkan, T. H. (2018). Formuvannia pedahohichnoi kultury batkiv molodshykh shkoliariv u vzaiemodii simi i shkoly [Formation of pedagogical culture of parents of junior schoolchildren in the interaction of family and school]. Candidate's thesis. Chernivtsi. 340 p. [in Ukrainian].

Стаття надійшла до редакції 03.11.2020

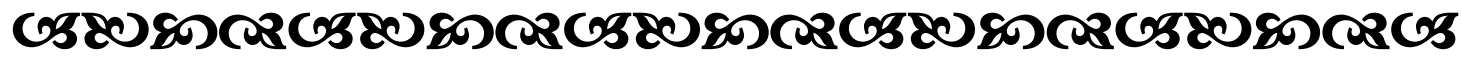

"Е дуже иікава зақономірність педагогічної пращі: передача знань не відбувається прямолінійно - ось це учитель съогодні взнав $і$ ось це він передає свойм вихованиям. Убоге и обмежено життя школярів, учитель яких поқладається лише на те, що напередодні уроку ніде івізвме те, що необхідно відаати, передати. У справжнього вчителя - найважие $i$ найрадісніше життя, трепетно хвилююча $i$ болісно складна творчість, незбагненно тонқі і вічновдосконалювані інструменти, яқими він діє на людсьқу душу".

Василь Сухомлинський український педагог, публіиист, письменник, поет

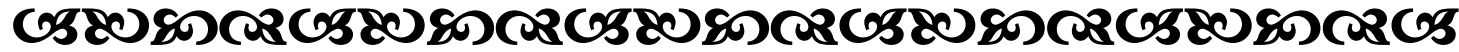

